Vol 1. No 2. Agustus 2017

ISSN 2580-5029

\title{
Potensi Bakteri Penambat Nitrogen dan Penghasil Hormon IAA Dari Sampel Rhizosfer Paku Epifit Di Mulut Gua Anjani, Kawasan Karst Menoreh
}

\author{
Andi Joko Purnomo ${ }^{1}$, Anisa Anggraeni' ${ }^{1}$, Rini Kusuma Astuti' ${ }^{1}$, \\ Agustina Budi Lestari ${ }^{1}$, Galuh Ajeng Antasari ${ }^{1}$ \\ ${ }^{1}$ BSG (Biospeleology Studien Gruppen), Kelompok Studi Biospeleologi, Jurusan Pendidikan \\ Biologi FMIPA UNY, Yokyakarta, Indonesia \\ *andi_perfect60@yahoo.co.id
}

\begin{abstract}
ABSTRAK:
Gua Anjani merupakan salah satu gua horizontal yang terletak pada kawasan karst Menoreh, Purworejo, Jawa Tengah.Gua memiliki ekosistem spesifik dengan berbagai organisme pembentuk ekosistem gua, salah satunya bakteri penambat nitrogen.Bakteri penambat nitrogen merupakan bakteri yang berperan dalam penyediaan nitrogen pada tanah karena bakteri tipe ini mampu menambat nitrat dengan mengoksidasi ion ammonium pada tanah sehingga dapat terikat dengan kuat pada komponen-komponen humus yang menyebabkan nitrat tidak mudah terbilas keluar tanah (Schlegel, 1994). Bakteri penambat N lebih banyak dijumpai pada daerah rhizosfir, sedangkan paku epifit banyak ditemukan di mulut gua. Dalam penelitian ini, peneliti akan mengkarakterisasi bakteri penambat nitrogen dan penghasil hormone IAA, menghitung kelimpahannya dan menganalisis kemampuan bakteri tersebut dalam menambat nitrogen sehingga dapat dijadikan salah satu landasan untuk mengembangkan dan memanfaatkan bakteri ini secara lebih lanjut. Bakteri ini akan diisolasi dari sampel tanah yang ada di Gua Nguwik di Kawasan Karst Menoreh, Purworejo, JawaTengah. Berdasarkan penelitian didapatkan hasil pengukuran fiksasi nitrogen pada media NB dengan panjang gelombang 420 $\mathrm{nm}$, pada jam ke 24 didaptkan hasil, isolat T1 memiliki rerata 0,416, G2 sebesar 0,408, dan R2 sebesar 0,402. Kemudian pengukuran pada jam ke 48 didapatkan hasil rerata untuk T1 sebesar 0,457, G2 sebesar 0,635 dan R2 sebesar 0,628. Kemudian dari hasil pengukuran terhadap kepadatan sel pada media NFM diketahui bahwa pada jam ke 24, isolat T1 memiliki rerata 1,605, G2 sebesar 1,682 dan R2 sebesar1,679. Kemudian pada jam ke 48 didapat rerata T1 sebesar 1,764, G2 sebesar 1,725 dan R2 sebesar 1,773.
\end{abstract}

Kata Kunci: Bakteri penambat nitrogen, Gua Anjani, hormone IAA, paku epifit, rhizosfer

\section{PENDAHULUAN}

Karst adalah suatu kawasan yang memilki karakteristik relief dan drainase yang khas, terutama disebabkan oleh derajat pelarutan batu batuannya yang intensif (Ford dan Williams, 1989).
Bentang alamnya yang unik merupakan sisi luar (eksokarst) dan di bawah permukaannya (endokarst), termasuk gua.

Gua memiliki lingkungan yang unik dan rentan terhadap perubahan, kondisi 
yang khusus ini menjadikan gua memilik ekosistem yang spesifik (Rahmadi Cahyo, 2008). Ekosistem gua yang spesifik dicirikan dengan keragaman habitat, yang seragam dalam kegelapan, kelembaban yang tinggi, variasi temperatur yang kecil mendekati 9 rata-rata tahunan lokal dan hampir tidak adanya aliran udara. Salah satu organisme yang ikut membentuk ekosistem di dalam gua adalah mikroba yang ada di dalam tanah.

Bakteri penambat nitrogen merupakan bakteri yang berperan dalam penyediaan nitrogen pada tanah karena bakteri tipe ini mampu menambat nitrat dengan mengoksidasi ion ammonium pada tanah sehingga dapat terikat dengan kuat pada komponen-komponen humus yang menyebabkan nitrat tidak mudah terbilas keluar tanah (Schlegel, 1994).

Hasil penelitian, menunjukkan bahwa mikroba penambat $\mathrm{N}$ (Azospirillum sp, Azotobacter sp, Aerosomonas sp. dan Aspergillus sp.) memiliki kemampuan ganda dalam penambatan nitrogen bebas dari udara sekaligus sebagai pemantap agregat tanah. Penelitian Wedhastri (2002), menyimpulkan bahwa dari beberapa strain hasil isolasi dan seleksi mikroba penambat $\mathrm{N}$ (Azotobacter) mempunyai kemampuan ganda dalam menambat nitrogen dari udara, juga sebagai penghasil zat pengatur tumbuh. Hampir seluruh isolat bakteri penambat $\mathrm{N}$ yang diisolasi dari tanah masam, terbukti sebagai penambat nitrogen bebas dari udara serta mampu menghasilkan fitohormon Indol Acetic Acid (IAA) dan Gibrelic Acid.

Dalam tanah bakteri penambat $\mathrm{N}$ lebih banyak dijumpai pada daerah rhizosfir dari pada daerah non-rhizosfir sedangkan paku epifit banyak ditemukan di mulut gua. Kondisi rhizosfir yang optimal bagi pertumbuhan bakteri penambat $\mathrm{N}$ akan menyebabkan $\mathrm{N}$ yang ditambatnya semakin maksimal. Lingkungan rhizosfir yang sangat mempengaruhi kehidupan bakteri penambat $\mathrm{N}$ adalah ketersediaan senyawa karbon (C) yang dibutuhkan. Dalam penelitian ini, peneliti akan mengkarakterisasi bakteri penambat nitrogen dan penghasil hormone IAA, menghitung kelimpahannya dan menganalisis kemampuan bakteri tersebut dalam menambat nitrogen sehingga dapat dijadikan salah satu landasan untuk mengembangkan dan memanfaatkan bakteri ini secara lebih lanjut. Bakteri ini akan diisolasi dari sampel tanah yang ada di Gua Nguwik di Kawasan Karst Menoreh, Purworejo, Jawa Tengah. Adapun tujuan penelitian ini adalah untuk mengetahui karakter 
morfologi koloni bakteri yang dapat menambat nitrogen dari sampel rizosfer paku epifit dari mulut Gua Anjani di Kawasan Kars Menoreh, Purworejo, Jawa Tengah, mengetahui karakter morfologi koloni bakteri yang dapat menambat nitrogen dari sampel rizosfer paku epifit, mengetahui isolat bakteri penambat nitrogen dan penghasil hormone IAA yang memiliki kepadatan sel tertinggi, serta mengetahui aktivitas fiksasi nitrogen dan produksi hormon IAA dari bakteri sampel rizosfer paku epifit dari mulut Gua Anjani di Kawasan Kars Menoreh, Purworejo, Jawa Tengah.

\section{METODE}

Penelitian ini dilaksanakan pada bulan Juli hingga September 2014 dengan tempat pengambilan sampel bakteri patogen yang ada di Gua Nguwik Kawasan Karst Menoreh, Purworejo, Jawa Tengah kemudian mengisolasi dan mengidentifikasi karakter bakteri patogen, tingkat patogenitas dan menghitung kelimpahannya di Laboratorium mikrobiologi FMIPA UNY.

Alat alat yang digunakan dalam penelitian ini adalah kain kassa, kapas, kertas payung, kertas cakram, botol kultur. Bahan yang digunakan ialah rhizosfer yang diisolasi dari tumbuhan paku epifit di daerah ulut gua anjani, reagen salwski, NA (Nutrient Agar), NB (Nutrient Broth) Media Nitrogen free Mannitol (NFM), alkohol, akuades.

\section{Pengambilan data dan Pengolahan data}

Pengambilan beberapa sampel paku dilakukan secara acak dengan teknik septik menggunakan skalpel steril, dan disatukan dalam plastik klip.Kemudian diberi label. Sampel dimasukkan dalam media NFM cair dan dishaker selama 2448 jam. Sampel kemudian diencerkan menggunakan $\mathrm{NaCl}$ fisiologis dengan taraf pengenceran 10-4 hingga 10-6. Isolasi bakteri penambat nitrogen dilakukan dengan menggunakan medium pertumbuhan NFM. Bakteri diinkubasi selama 48 jam, dan diamati koloni yang tumbuh..Isolat tersebut dikarakterisasi yang meliputi morfologi koloni dan fenotipik sel.

Uji fiksasi $\mathrm{N}$ diudara dilakukan berdasarkan metode Ikhwan (2006). Kemampuan penambatan N2 diukur dengan menghitung N2 yang terlarut dalam air dalam bentuk NH4 menggunakan spektrofotometer dengan panjang gelombang $420 \mathrm{~nm}$ dan dengan penambahan reagen salkowski. Isolatisolat bakteri endofit ditumbuhkan pada media NB cair dan di inkubasi dalam shaker inkubator selama 24 jam. 
Pengukuran kepadatan bakteri dilakukan dengan menanam isolat pada media NFM cair dan menshaker serta menginkubasinya dalam suhu ruang. Isolat kemudian diukur menggunakan spektrofotometer panjang gelombang $600 \mathrm{~nm}$.

\section{Teknik analisis data}

Teknik analisis data menggunakan analisis deskriptif untuk data karakter fenotipik bakteri penambat nitrogen, kepadatn sel bakteri penambat nitrogen dan penghasil hormon IAA.

\section{HASIL DAN PEMBAHASAN}

Hasil penelitian yang dilakukan disajikan dalam tabel berikut.

Tabel 1. Fiksasi nitrogen dan kepadatan sel

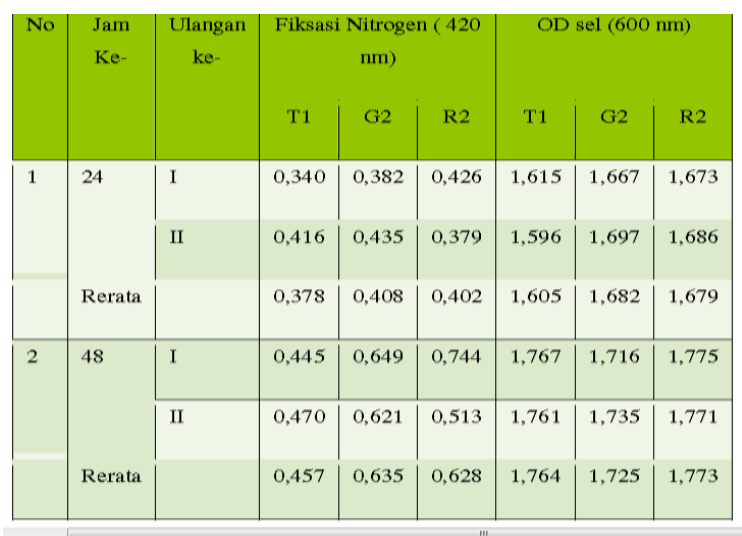

Berdasarkan hasil pegamatan total keseluruhan isolat bakteri yang didapatadalah 4 koloni bakteri dengan karakter yang sama. isolat ini dilabeli J1, T1, R2,dan G2. Dari hasil pengujian, diketahui bahwa isolat bakteri penambat nitrogen memiliki karakteristik warna transparan, dengan tepian entire, bentuk koloniround, elevasinya konveks dan ia merupakan bakteri anaerob fakultatif. Dalam hal ini hanya dilakukan karakterisasi dikarenakan pengujian untuk mengetahui jenisbakteri secara lebih lanjut tidak memungkinkan, dan dalam tujuan pun hanya karakterisasi saja yang dituju.

Hasil pengujian kepadatan sel pada media NFM hari ke 0 dengan panjang gelombang $600 \mathrm{~nm}$, diketahui bahwa isolat J1 memiliki rerata kepadatan sel 1,42,isolat $\mathrm{T} 1$ sebesar 1,555 , isolat $\mathrm{R} 2$ 1,595, dan isolat G2 sebesar 1,580. Sehingga dapat dikatakan isolat T1, R2, dam G2 merupakan 3 isolat bakteri yang memiliki rerata kepadatan sel terbesar. Ketiga isolat ini disebut isolate terpilih yang nantinya akan diukur setiap harinya baik kepadatan sel maupun aktivitas fiksasi nitrogennya.

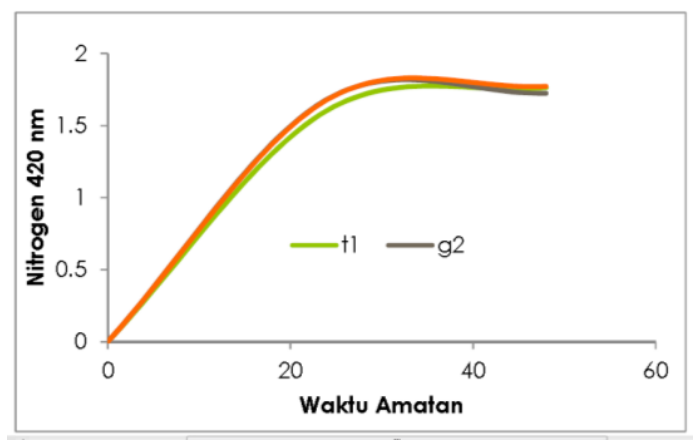

Gambar 1. Hasil pengukuran fiksasi nitrogen pada media NB dengan panjang gelombang $420 \mathrm{~nm}$

Hasil pengukuran fiksasi nitrogen pada media NB dengan panjang 
gelombang $420 \mathrm{~nm}$, menghasilkan hasil yaitu pada jam ke 24, isolat T1 memiliki rerata 0,416, G2 sebesar 0,408, dan R2 sebesar 0,402. Kemudian pengukuran pada jam ke 48 didapatkan hasil rerata untu T1 sebesar 0,457, G2 sebesar 0,635 dan R2 sebesar 0,628.

Dari grafik tersebut, dapat dilihat bahwa aktivitas fiksasi nitrogen munculsetelah jam ke 24 penanaman bakteri, dan dari ketiga isolat yang digunakan ketiganya cenderung mengalami sedikit penurunan aktivitas dalam memfiksasi nitrogen. Penurunan ini dimungkinkan karena bakteri sudah mulai memasuki fasekematian sehingga kemampuan bakteri dalam memfiksasi nitrogen menjadi turun. Aktivitas fiksasi nitrogen sendiri menurut Marschner (1986) menyatakan bahwa bakteri akan mengaktifkan enzim nitrogenase untuk memfiksasi dan mereduksi Nudara menjadi gugus $\mathrm{NH} 2$ yang kemudian dirangkai dengan rantai karbon menjadi senyawa amina atau asam amino yang merupakan komponen dasar dalam pembentukan protein dan pembentukan organel sel yang lain.

Kemudian dari hasil pengukuran terhadap kepadatan sel pada media NFM diketahui bahwa pada jam ke 24, isolat T1 memiliki rerata 1,605, G2 sebesar 1,682 dan R2 sebesar 1,679. Kemudian pada jam ke 48 didapat rerata $\mathrm{T} 1$ sebesar 1,764, G2 sebesar 1,725 dan R2 sebesar 1,773. Dan jika digambarkan dalam grafik maka:

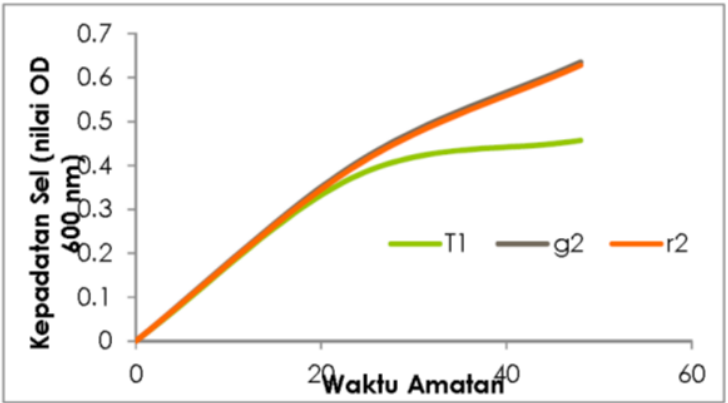

Gambar 2. Hasil pengukuran terhadap kepadatan sel pada media NFM

Dari grafik terlihat bahwa kepadatan sel tertinggi seimbang antara isolate G2 dan R2. Dimana kedua isolat ini terus mengalami peningkatan kepadatan selpada jam ke 48. Sementara isolat $\mathrm{T}$ memiliki kepadatan sel terendah. Untuk mengetahui kemampuan bakteri dalam menghasilkan hormon IAA maka hasil pengukuran aktivitas bakteri dalam memfiksasi nitrogen kemudian dibandingkan dalam kurva standar IAA, yaitu sebagai berikut:
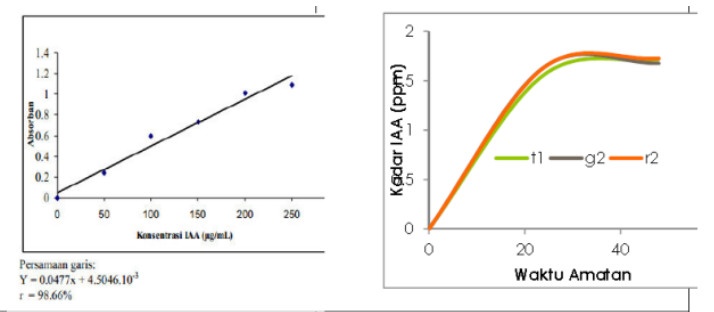

Gambar 3. Perbandingan aktivitas bakteri dalam memfiksasi nitrogen dalam kurva standar IAA 
Dari hasil tersebut dapat terlihat bahwa terdapat penyimpangan pada kurvafiksasi nitrogen terhadap kurva standar IAA. Hal tersebut menunjukkan bahwa bakteri kurang mampu memproduksi IAA ekstra selular secara optimal. Kecilnya produksi IAA ekstra selular kemungkinan karena secara genetik bakteri dari rihizosfer tersebut kurang mampu mensintesa IAA ekstra selular. Untuk menghasilkan IAA ekstraselular dalam jumlah yang banyak. IAA sendiri disintesis sebagai metabolit sekunder yang dihasilkan dalam kondisi pertumbuhan bakteri suboptimal atau saat tersedia prekursor asam amino triptofan (Lucyanie, 2009).

\section{KESIMPULAN}

Berdasarkan hasil penelitian yang telah dilakukan, disimpulkan beberapa hal sebagai berikut. Isolat bakteri dari sampel rizosfer paku epifit dari mulut Gua Anjani, Purworejo, Jawa Tengah diperoleh 4 isolat yang memiliki karakter morfologi koloni yang sama. Isolat yang memiliki nilai kepadatan sel tertinggi adalah T1,G2,dan R2.Aktifitas bakteri menghasilkan hormon IAA berbanding lurus dengan kepadatan sel bakteri, dan kemampuan penambat nitrogen.

\section{DAFTAR PUSTAKA}

Aryantha, I..P., Dian, P.L., dan P.D.P Nurmi. 2004. Potensi Isolat BakteriPenghasil Iaa Dalam Peningkatan Pertumbuhan Kecambah Kacang HijauPada Kondisi Hidroponik. Mikrobiol Indones. 9: 43-46.

Bashan, Y., and G. Holguin. 1998. Proposal for The Division of Plant GrowthPromoting Rhizobacteria into Two Classifications Biocontrol PGPB(Plant Growth-Promoting Bacteria) and PGPB. Soil Biol Biochem. 30:1225-1228.

Ford, D. and P. William. 1992.Karst Geomorphology and Hydrology.

Chapmanand, H., London, I., and K. Kyuma. 2004. Paddy Soil Science.Kyoto University Press and Trans PacificPress.

Ladha, J. K. and P. M. Reddy. 1995. Extension of Nitrogen fixation to rice:necessity and possobillities. Geo Journal 35:363-372.

Lucyanie, D. 2009. Pengaruh Penambahan Bahan Organik yang MengandungTriptofan (TRP) terhadap Produksi Asam Indol Asetat (AIA) olehAzospirillum spp. Strain Lokal.Skripsi. Bandung: ITB.

Marschner 1986 dalam Tarigan, Ratnasari., Jamilah, IT., Elimasni. 2014. SeleksiBakteri Penambat Nitrogen Dan Penghasil Hormon IAA (Indole AceticAcid) Dari Rizosfer Tanah Perkebunan Kedelai (Glycine Max L.).Sumatera: Universitas Sumatera Utara.

Rahmadi , C . 2007. Arthropoda Gua Karst Maros (Sulawesi) dan Gunung 
Sewu(Jawa):melintas garis Wallace.

Fauna Indonesia 7.

Salisbury, B., Frank., dan C.W. Rosse. 1992. Fisisologi Tumbuhan Jilid 2. ITB:Bandung.

Sastrapradja, S. 1979. Jenis Paku Indonesia. Jakarta: Balai Pustaka.Schlegel, H.G. dan Schmindt, K. 1994.Mikrobiologi Umum. Gajah MadaUniversity Press.Yogyakarta.

Wedhastri, S. 2002. Isolasi dan seleksi Azotobacter spp. Penghasil FaktorTumbuh dan Penambat Nitrogen dari Tanah Masam. J Ilmu Tanah Ling.3: 45-51. 